\title{
Polycyclic Evolution of Paleoproterozoïc Rocks in the Southwestern Part of the Mako Group (Eastern Senegal, West Africa)
}

\author{
Papa Moussa Ndiaye ${ }^{1 *}$, Edmond Dioh ${ }^{2}$, Famara Diatta1 ${ }^{1}$, Alassane Traore ${ }^{3}$, \\ Makhoudia Fall'1, Ousmane Balde ${ }^{1}$ \\ ${ }^{1}$ Département de Géologie, Université Cheikh Anta Diop, Dakar, Sénégal \\ ${ }^{2}$ Institut Fondamental d'Afrique Noire, Université Cheikh Anta Diop, Dakar, Sénégal \\ ${ }^{3}$ Institut de Technologie Nucléaire Appliquée, Université Cheikh Anta Diop, Dakar, Sénégal \\ Email: ${ }^{*}$ diayepm2@yahoo.fr
}

Received 30 April 2014; revised 28 May 2014; accepted 15 June 2014

Copyright (C) 2014 by authors and Scientific Research Publishing Inc.

This work is licensed under the Creative Commons Attribution International License (CC BY). http://creativecommons.org/licenses/by/4.0/

\section{cC) (7) Open Access}

\begin{abstract}
After an extensional stage giving rise to tholeiitic basalts and gabbros, the south western part of Kédougou Kéniéba Inlier (KKI) was affected by three phases of compressionnal deformation. The first phase (D1) was related to NE-SW stress that led to northeastward thrusting. Early granitoids would be implemented during this tectonic event. The second phase (D2) was due to East-West compressional stress that created combined strike sleep faults: NNW-SSE and NNE-SSW respectively sinistral and dextral. During this phase, some volcanic rocks and gabbros were mylonitized, hydrothermalized and transformed into quartzites. These quartzites were considered as sedimentary rocks in previous studies. Granitic plutons and andesites took place during this tectonic phase. D3 deformation occurred towards the end of the Eburnean orogeny. It would be held in two episodes. In the first episode, WNW-ESE stresses created conjugate shears: sinistral NNW-SSE and dextral NE-SW. In the second episode, stresses moved toward the NE-SW direction and made the resulting brittle structures arranged in NS dextral corridors.
\end{abstract}

\section{Keywords}

Paleoproterozoïc, Eastern Senegal, Volcanic-Rocks, Polycyclic Deformation, Silicification

\section{Introduction}

The Kédougou-Kéniéba Inlier (KKI) is part of the West African craton. It is characterized by two domains

*Corresponding author.

How to cite this paper: Ndiaye, P.M., et al. (2014) Polycyclic Evolution of Paleoproterozoïc Rocks in the Southwestern Part of the Mako Group (Eastern Senegal, West Africa). International Journal of Geosciences, 5, 739-748.

http://dx.doi.org/10.4236/ijg.2014.57066 
(Bessole, [1]; Black, [2]): 1) In the North, the dorsal Reguibat that spans Mauritania and western Algeria. This dorsal contains both archean and paleoproterozoic formations: the first outcrops in the southwest and the second in the East, 2) In the South, the Leo dorsal occupies a vast area including southern Mali, Guinea, Ivory Coast, Niger, Burkina Faso and Ghana. It is composed of an Archean area to the west and a large paleoproterozoic area to the east (Baoule Mossi domain). The Reguibat and Leo Dorsals are separated by Neoproterozoic to Phanerozoic sedimentary formations of the Taoudeni Basin. Between these two dorsals, outcrops the Kédougou-Kéniéba inlier at the confines of Senegal and Mali. The Kédougou-Kéniéba inlier consists mainly of Paleoproterozoic formations divided into two groups (Figure 1) (Bassot, [3]; Ndiaye et al., [4]; Theveniault et al., [5]): 1) To the west, the Mako group, considered as the oldest entity, is a tholeiitic volcanic complex (Dia, [6]; Diallo, [7]; Ngom, [8]; Dioh, [9]) cut by the Kakadian batholith dated around $2199 \pm 68 \mathrm{Ma}$ and 2168 Ma respectively by Bassot and Caen-Vachette, [10] and Dia, [6]; 2) To the east and above it, the Dialé-Daléma group dominated by sedimentary rocks and cut by an important calco-alcalin volcano-plutonic complex with a zircon age $2064 \pm 30$ Ma (Delor et al., [11]). The lithological succession (volcanic rocks then sedimentary rocks) is opposed to that which has been accepted in Ghana since Junner, [12] and throughout the West African Craton by Ledru et al., [13]. These authors propose to divide the Palaeoproterozoic (Birimian) into two structurally separated units: a lower Birimian (B1) substantially sedimentary individualized by an overlapping tangential tectonic (D1); and an upper volcanic Birimian (B2) post D1 affected by transcurrent deformations D2 and D3. Hirdes and Davis [14] obtained in the Kédougou-Kéniéba Inlier an age, 100 Ma lower than those ages found in the east (Ivory Coast, Ghana) and this led to subdividing the Paleoproterozoic of West Africa into two provinces: an older (2150 - $2190 \mathrm{Ma}$ ) eastern province (Ghana, Ivory Coast) and a younger (2080 - $2110 \mathrm{Ma}$ ). Guèye et al. [15] do not agree with this conclusion. In addition, Hirdes and Davis [14] proposed for the West African Eburnean orogeny an accretionnary tectonic model and diachroneous volcanic and sedimentary formations. According to Vidal et al., [16] a two-fold evolution marked the Eburnean orogeny. The first stage was characterized by the development of "domes and basins"

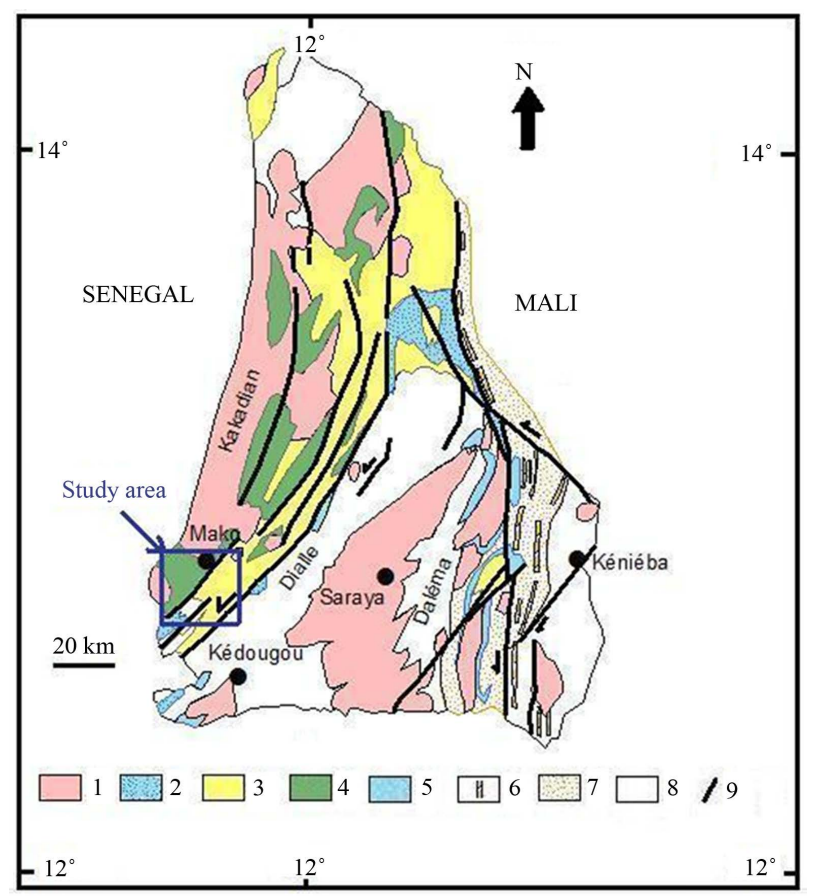

Figure 1. Geological map of the KKI. 1: undifferentiated granite; 2: deltaic formation (sandstone, conglomerate, argillite); 3 : andesitic to rhyolitic volcanic rock, chert and graphitic beds; 4 : basic volcanic rock, chert and manganeze level; 5: carbonate and altered acidic to intermediate volcanic rock; 6: tourmalinized sandstone; 7: felsic volcanoclastic rock and dyke, chert and manganese layer; 8: flysch type rock (sandstone to argillite with graphitic and conglomeratic layers). 
geometries without any boundary tectonic forces and the second stage was marked by coeval diapiric movements and horizontal regional scale shortening.

This shows that the ideas developed regarding the chronology of lithostratigraphic features are contradictory and as we will see in our present work, the debate is far from over. In this paper, we emphasize the field geometric relationships between the main rocks of the southern part of the Mako group (Figure 2) and try to answer the following questions: 1) Is the Mako group affected by a single phase deformation as previously proposed [13]? 2) What is the origin of quartzite associated with volcano-plutonic rocks of the Mako group? Are they sedimentary rocks as formerly suggested [3]?

\section{Lithology and Petrography}

\subsection{Metabasalts and Metagabbros}

These rocks form the hills overlooking the village of Mako. They are interbedded with volcano-sedimentary rocks comprising metabreccias and metatuffs. Metabasalts and metagabbros are intimately associated and there is no clean contact between them. These rocks belong to the same magma; metagabbros occupy the lower part and metabasalts, the upper part. Metabasalts are generally pillow lavas (Figure 3(A)). The pillows are usually distorted and have elliptical form. Their X axis, oriented NS, NE-SW or NNW-SSE can rise $130 \mathrm{~cm}$. Pillows are cemented by chlorite, epidote and quartz. Many pillows contain shelf structures indicating that these were lava tubes. Shelf structures resulted from repeated fillings of lava with the subsequent collapse of the thin congealed skin with the tube (Sawyer et al., [17]; More and Charlton, [18]). The attitudes of the shelf structure are parallel to the bedding plane of the lava flows confirming that these are gravity-controlled structures. Under the microscope metabasalts show a matrix of epidote, chlorite and actinolite made by the destabilization of former pyroxene. The matrix contains numerous albitized microlite of plagioclase and secondary quartz aggregates. The metagabbros are fine and coarse grained. Several spinifex structures are observed. Metagabbros contain altered plagioclase and augite type pyroxene being destabilized in green hornblende, chlorite, actinolite and oxide. In addition, secondary quartz is observed in these rocks.

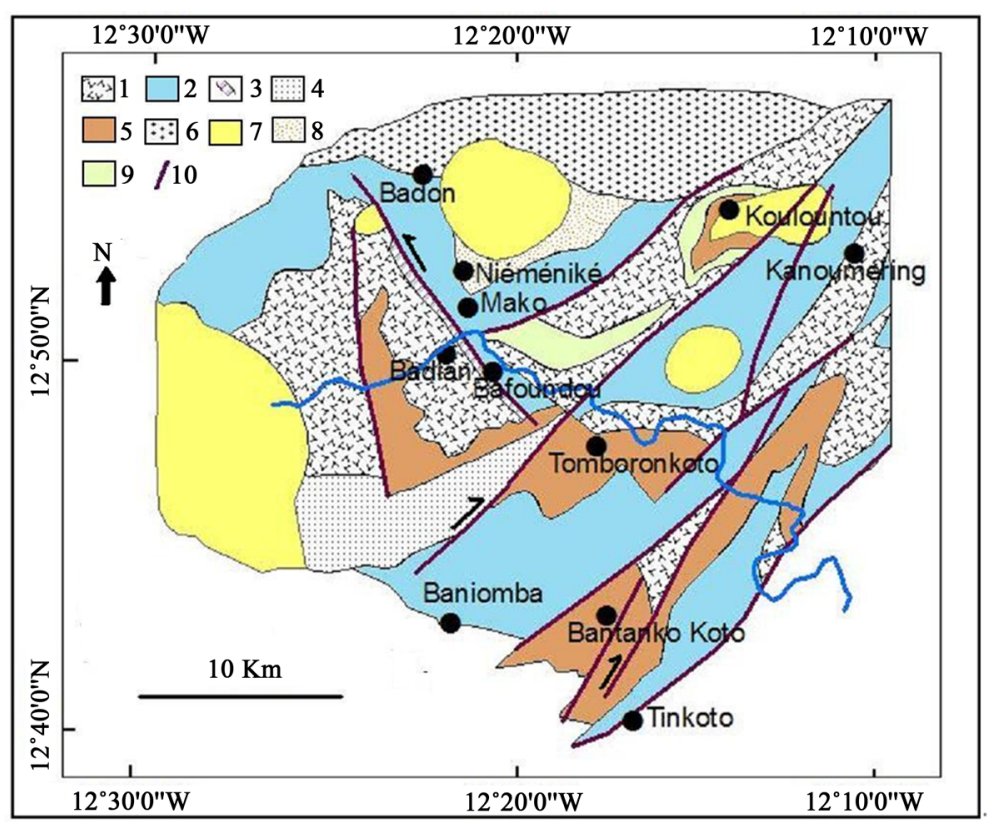

Figure 2. Geological skrech map of the south-western part of the KKI (Delor et al., 2010 modified). 1: pillow lavas metabasalts, metagabbros and metatuffs; 2: metatuffs, metabreccias, metacherts and metagreywackes; 3: hematitic quartzites; 4: metapelites and metagreywackes; 5: metaandesites, metarhyolites, metatuffs and metabreccias; 6: early granite and migmatite; 7: tardi tectonic granites; 8: tardi to post tectonic microgranites and rhyolites; 9: ultrabasic rocks; 10: ductile faults. 

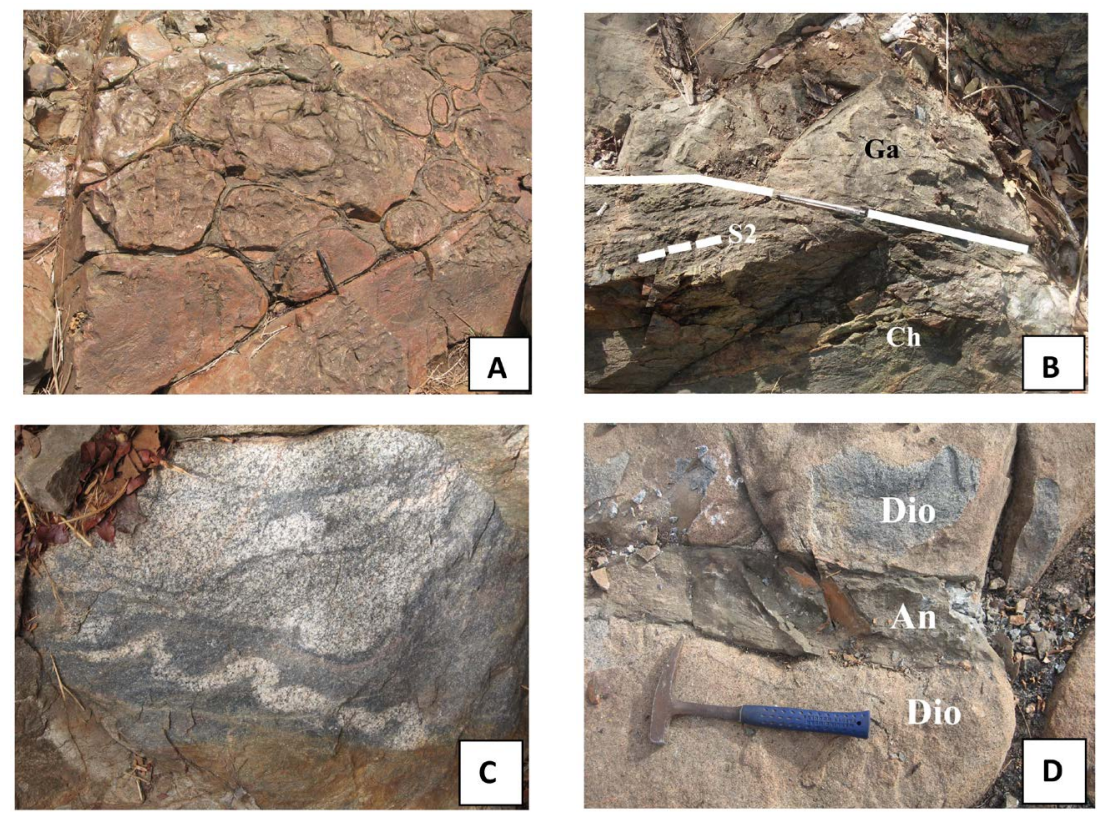

Figure 3. (A) Pillow lavas metabasalt; (B) Intrusion of a late gabbro (Ga) in a foliated chert (Ch); (C) Leucosome and asymmetric folds in a migmatite; asymmetry indicates top-to-the-right movement; (D) Injection of a late andesitic (An) dyke in a diorite (Dio).

\subsection{Metabreccias and Metatuffs}

These rocks outcrop around Bafoundou village. Their original bedding is sometimes well preserved and marked by an alternation of fine metatuffs and metabreccias. The rocks are generally dark in color but sometimes there are clearer rhyolitic metatuffs. In Mako village, outcrops of rhyolitic metatuffs are characterized by their high degree of kaolinization. Under the microscope, dark metatuffs show a chloritic matrice with various stretched fragments of rock. Sandstone, tuff and basic volcanic rocks are the more observed fragments. Secondary crystallized quartz is also present. In the intensely sheared rocks, aggregates of epidote are observed.

\subsection{Metacherts}

These rocks, very often, are confused with mylonitized metabasalts. They are characterized by their dark green color and an alternating light quartz-rich bed and dark hematite-rich bed. They are interbedded with metagabbros and metabasalts. The banded cherts are generally highly deformed and have a cleavage parallel to the bedding. They are often associated with discordant gabbro that cut the foliation (Figure 3(B)). In the outcrops near granitoïds, these rocks contain chlorite and white mica.

\subsection{Granitoïds}

Granitoids exposed in the study area have been classified previously among intrusive bodies. Their size is small compared to those of large elongated bodies like Saraya or Badon Kakadian (Figure 1) batholiths. They were observed at Nieméniké and its surroundings. They cut metabasalts and metagabbros. Granitoids are associated with microgranites, rhyolites, aplites and pegmatite veins. Regarding tectonic consideration, two types of granitoids were observed: some highly deformed, and others little deformed or without deformation. Petrographically, facies are varied: diorite, granodiorite and granite. Granodiorites are more represented. Their granular texture is composed of amphibole changed into chlorite and opaque minerals, zoned plagioclase, anhedral quartz and microcline. A secondary assemblage of epidote, calcite and sericite is often observed.

\subsection{Migmatites}

A mixture of gneiss and granite was observed at the west of Niéméniké. The gneiss has a characteristic foliation 
consisting of alternating clear quartzofeldspathic beds and biotite-rich dark beds. The clear beds show feldspar phenocrysts whose borders were recrystallized. The same phenomenon is also observed in the plagioclase crystals. Many aggregates of microcline made by the recrystallization of feldspar are very common. Gneiss is cut by veins of granite, which shows under the microscope an association of quartz, feldspar and rare biotite. Secondary muscovite are present. They come from the destabilization of feldspar and biotite especially in silicified zones. In addition we observe many zircon crystals intimately associated with biotite. Gneiss is an ancient granite or rhyolite strongly metamorphosed, foliated and folded. Then it was affected by the beginning of a partial melting that liquefied some minerals (quartz, feldspar and some mica). This liquefied part came together after a weak migration within the foliation and developed granite lenses (leucosome). The foliated biotite-rich gneiss represents the unmelted part (melanosome). The leucosome is affected by asymmetric folds that indicate a dextral shear (Figure 3(C)).

\subsection{Meta-Andesites}

These rocks are exposed in the eastern part of the study area. It is an association of lavas and andesitic metatuffs and metabreccias. Lavas show a porphyritic microlitic texture with phenocrysts of pyroxene and amphibole. In the localized shear zone, rocks are highly deformed; ferromagnesian minerals are transformed into large black spots. Andesitic breccias contain angular elements predominated by meta-andesites joined by a tuff cement. The stratification is marked by the alternating of coarse beds and fine beds. It is N30E oriented and inclined $50^{\circ}$ to the SE. The major cleavage is sub vertical and the average direction is N25E. Under the microscope the texture is predominated by amphiboles compared to pyroxene. The heart of some amphiboles shows the remains of early altered pyroxene. The mylonite of andesitic metabreccias look like amphibolites predominated by stretched and sheared amphibole (Figure 5(A)). The shear planes are marked by the presence of chlorite. In addition, these rocks show clasts of pyroxene transformed into epidote, chlorite and iron oxide.

\subsection{Ultrabasites}

They form two hills. One on the western Mako (the smallest) globally oriented WNW-ESE. The second, more important, forms a trail ENE-WSW. They differ from other igneous rocks by their blackish color and their high density. The rocks present a magmatic layering: the center is ultrabasic and the border is gabbroic. The more differentiated facies are pegmatitic gabbros. Ultrabasic terms consist of Wherlites and lherzolites, the basic terms represent websterites orthopyroxene gabbros, ferrogabbros and pegmatitic gabbro (Ngom, [8]; Cissoko, [19]).

\subsection{Late Gabbro and Andesite}

Late gabbros occur in dykes of $55 \mathrm{~cm}$ large, oriented N40, intersecting banded cherts (Figure 3(C)). Their microgranular texture consists of microcrystals of pyroxene and plagioclase. These often are small elongated rods. Pyroxenes, meanwhile, are euhedral and often epidotized. Late andesites cut a diorite (Figure 3(D)) rich in enclaves. This diorite outcrops at the north of Niéméniké village. Late andesites occur as veins with a maximum width of $15 \mathrm{~cm}$ sometimes arranged in echelon. The placement of these veins is controlled by N130 dextral fractures. Late andesite have porphyritic microlithic texture with phenocrysts of plagioclase and pyroxene. Pyroxenes are euhedral and often twinned. Euhedral plagioclase without preferential orientation are scattered throughout the mesostase formed essentially by microlites of plagioclase and pyroxene.

\subsection{Hematitic Black and White Quartzites}

Black and white hematitic quartzites are usually sandwiched between metatuff-metabreccia on the one hand and the associated metagabbros-pillow metabasats on the other hand. They are mainly characterized by their banding (Figure 6(A)). There is a transition zone between quartzite and the associated metagabbro-metabasalts. In this transition zone these basic rocks intruded by numerous quartz veins (Figure 6(B)), are in the process of silicification. Quartzites associated with metagabbros show relic of primary texture (Figure 6(C)). The contact between quartz veins and basic rock is marked by the presence of epidote. Very often at the site of contact between metatuffs and quartzite there is a sericite-chlorite mylonite. Under the microscope rocks are heterogranular (Figure 6(D)). White beds are mainly constituted by quartz and black beds are rich in hematite that occurs as anhedral disseminated grains or aggregate of subhedral crystals. 


\section{Polyphase Deformation}

After an extensional stage giving rise to tholeiitic basalts and gabbros, the south western part of Kédougou Kéniéba inlier was affected by three phases of compressionnal deformation (D1, D2 and D3).

\subsection{Thrusting Structure (D1)}

It affects mainly metatuffs (Figure 4(A)) associated with metabasalts. These rocks are characterized by a stretching lineation well marked by elongated pebble with $30^{\circ}-60^{\circ}$ dip to the SSW. This stretching lineation is carried by a S1 schistosity that strikes N160. The schistosity planes are sometimes, parallel to tangentiel shear planes. Under the microscope, schistosity is marked by white mica and chlorite. In addition, C' shear bands are observed in metatuffs associated with hematitic mylonitic quartzites. The orientation of these bands indicates a transport towards the NNE.

\subsection{Ductile Strike-Slip Faults (D2)}

Rocks in some areas are affected by vertical shear in two tectonic corridors: NNW-SSE and NNE-SSW. In the first corridor, the S1 cleavage was straightened and redirected (Figure 4(B)). Metatuffs and metabreccias were particularly affected. The deformation can be very intense in those corridors where rocks are very mylonitized showing S/C structures that clearly indicate sinistral shear (Figure 4(C)). Outside these corridors deformation is barely visible. In the NNE-SSW corridors metatuffs and metacherts show respectively microfolds (Figure 4(D)) and domino structure (Figure 5(A)) that indicate dextral shear. S2 foliation associated with these vertical shear is most prevalent in the study area. In addition, highly ductile chloritic bands of meta-andesite are affected by a S3 schistosity (Figure 5(B)).

\subsection{Semi Ductile to Brittle Structures (D3)}

Metatuffs and metabasalts show many semi ductile structures represented by simple fissures in echelon or in conjugated system. The sinistral N150 corridor and the dextral N80 corridor are the two most common systems combined in the study area. En-echelon tension gash veins are often developped in the dextral N80 corridor (Figure 5(C)). The main stress that created these conjugated shear are on average oriented ESE-WNW. Other
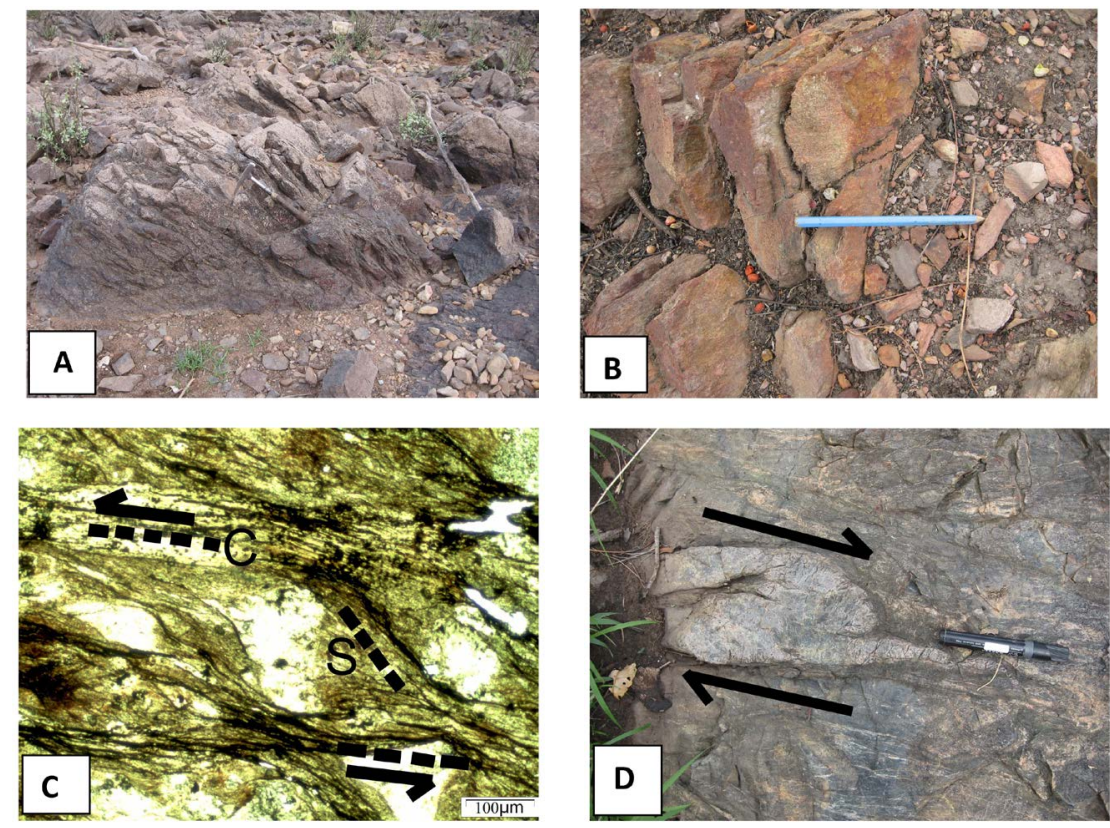

Figure 4. (A) Metatuff showing thrusting structure (D1 phase); (B) Metatuff showing a subvertical schistosity (S2, D2 phase); (C) S/C structure indicating sinistral shear (D2 phase); (D) Asymmetric fold in a metatuff indicating dextral shear (D2 phase). 

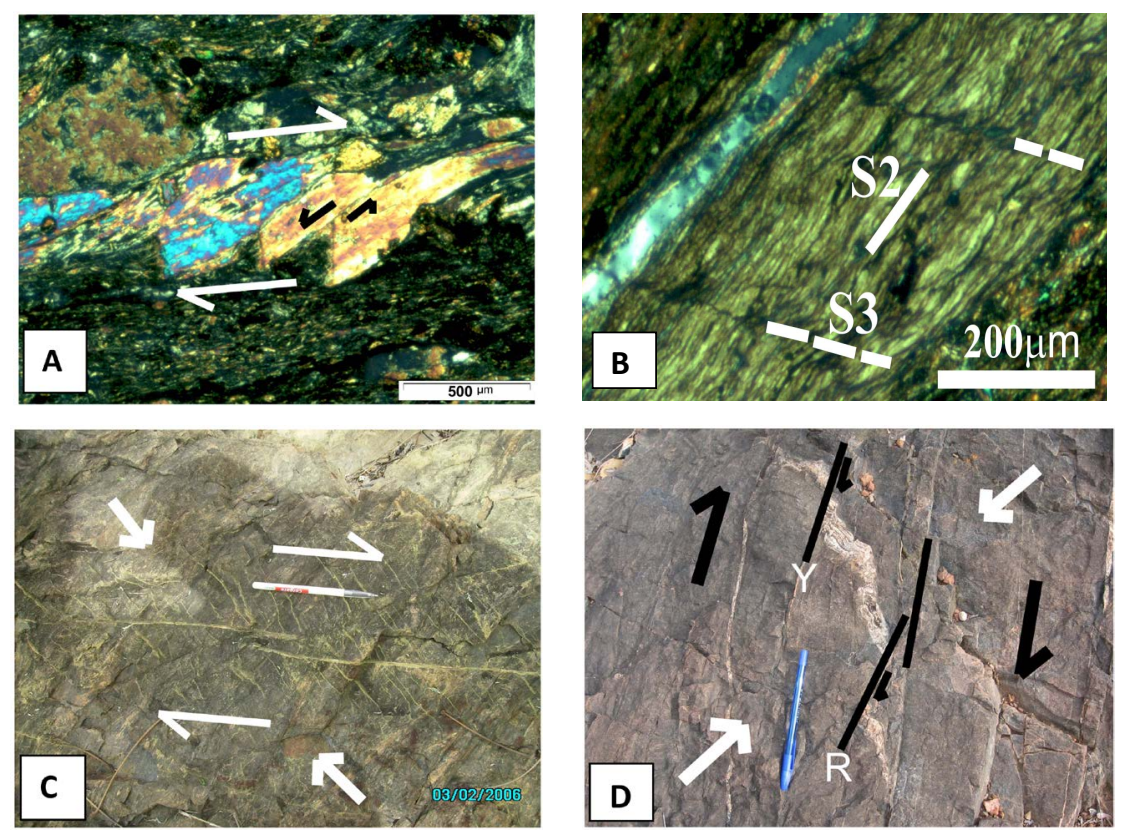

Figure 5. (A) Dextral ductile shear in meta-andesite (D2 phase); (B) S3 schistosity in a chloritic layer (continuation of D2 phase); (C) En-echelon tension gash veins developped in a dextral N80 corridor; (D) N-S dextral brittle shear (D3) showing Y and R Riedel faults.

structures related to D3 deformation are Riedel faults that appeared in the late North-South dextral shear zone. Most represented are Y and R Riedel faults (Figure 5(D)). These shear zones are in extension and are cut by numerous quartz veinlets. They are due to NE-SW compression.

\section{Interpretation and Discussion}

The southern part of Mako Group includes pillow metabasalt associated with metagabbros. These rocks are a volcano-plutonic stack, the first on the upper part and the latter on the lower part. These tholeiitic rocks appeared during an extensional phase. According to Cissokho, [19] metabasalts and metagabbros appeared in a shallow marine environment. They are associated with metatuffs and metabreccias.

The inventory of microstructures and their mutual relations in space and time allow to propose that the south western part of the Mako group, after the extensional phase, was affected by a polyphase deformation. A first compressional event is related to SSW-NNE stress instigated thrusts (D1) towards the NE. Metabasalts and metagabbros were intensely deformed and some pillows were reversed and folded. They overlap metatuffs and associated rocks. During this compressive phase, some granitoïds occur cutting metagabbros and metabasaltes. Then, E-W stress created combined transcurrent shear (D2): sinistral NNW-SSE and dextral NNE-SSW. During this tectonic event, others granites and some andesites were emplaced. Towards the end of the Eburnean orogeny, occurred D3 deformation. This would be held in two episodes. At first WNW-ESE stress, created conjugated shear: sinistral NNW-SSE shear and NE-SW dextral shear. In a second step, stress moved toward the NE-SW direction and made the resulting brittle structures arranged in NS dextral corridors. The idea of an early phase of tangential deformation has already been mentioned by Ledru et al., [13] and Diène et al., [20]. According to these authors this tangential phase is followed by two separate transcurrent tectonic events named D2 and D3. However, Delor et al., [11] do not agree with the hypothesis of an early tangential event and argue instead for a tectonic transcurrent continuum with two successive stages of deformation. The first step is responsible for a regional early cleavage. The second stage is marked by a second generation of folds that deformed the early cleavage. Our observations are similar to those proposed by Ledru et al., [13] and those of Diène et al., [20]. However, there is some dissimilarity. Indeed, contrary to our observations, Ledru et al., [13], consider that the tangential tectonic phase does not affect tholeiitic metabasaltes and metagabbros. Diène et al., [20], consider that vertical shear occurred during two separate transcurrent events (D2 and D3). According to our observations those are conjugate 
structures.

In the study area, outcrops of quartzites are oriented NNW-SSE along the massif of metabasalts and metagabbros from Bafoundou to northwestern Nieméniké (Figure 2). As we noted above, these rocks have been described previously as sedimentary rocks (Bassot [3]). In fact, quartzites outcrops in a mylonite zone affecting metabasalts, metagabbros, metabreccias and metatuffs. These rocks are highly deformed and partially or completely silicified. Relics of primary texture remain especially in quartzites associated with metagabbros (Figure 6(C)). From NNW to SSE, we consistently observed an intermediate zone between quartzite and basic rocks where these are partially silicified but cut by numerous veins of quartz. Similar black and white quartzites were reported by Wilson and Versfield, [21] in the greenstone belt of South Nondweni Kaapwaal Craton (South Africa). Several types of training processes of these quartzites were considered: ash deposits in a shallow environment followed by chemical precipitation of silica exhalative origin (Wilson and Versfield, [21]). Eugster and Jones, [22] reported the presence of sodium-silicate gel in Magadi Lake (Kenya) that made siliceous band. Naqvi et al., [23] consider that cherts of Indian archean greenstone belt came from the chemical precipitation of exhalative volcanic product. Regarding the quartzite in eastern Senegal, the lack of sedimentary structure and the discontinuity of the black-white bands exclude a primary sedimentary origin. Similarly, the idea of a chemical precipitation of silica could be ruled by strong recrystallization of quartz grains (Figure 6(D)). We believe that quartzites could come from ultramylonitisation of metabasalts, metagabbros and metatuffs. This tectonic phase is accompanied by a significant fluid flow, an intense epidotisation and silicification of the rocks. Two types of quartzites were noted: black and white quartzites that seem to derive from metabasalts or metagabbros and white quartzites that may arise from the transformation of metatuffs. The black color of some bands is due to a high concentration of hematites, which comes from the destabilization of former mafic minerals or iron sulfides. Some quartzites which exhibit a remnant texture of metagabbros have abnormally high heavy metal content $(\mathrm{Cu}, \mathrm{Fe}, \mathrm{Zn}, \mathrm{Cr})$ which is not consistent with a clastic sedimentary origin of these rocks.

\section{Conclusion}

The Mako Group in the western part of the Kédougou-Kéniéba inlier consists of tholéiitic metabasalts and metagabbros associated with metabreccias, metatuffs and quartzite. It is intersected by various acid to intermediate and ultrabasic intrusions. After an extensional phase, which gave rise to the emplacement of the tholeitic rocks,
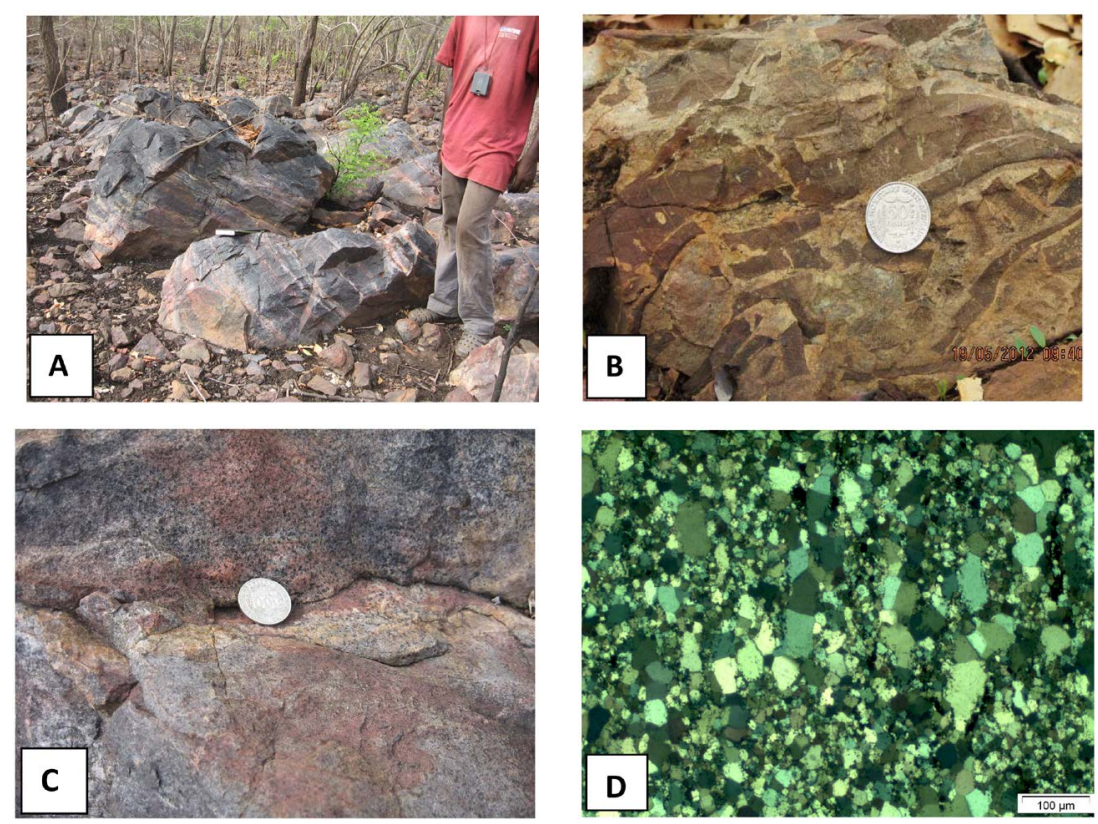

Figure 6. Silicification of basic rocks. (A) Mylonitic zone showing total silisification of a metagabbro; note bands of quartz slightly dipping to the NW; (B) Intermediate zone showing stockwerk of quartz in a partially silicified metagabbro; (C) Silicified metagabbro showing relics of primary texture; (D) Microtexture of silicified metagabbro. 
three major tectonic phases characterized the Eburnean cycle in this part of the West African Craton. An early stage of tangential tectonics (D1) due to compressive stress oriented SSW-NNE that caused thrust and transport towards the NE. The second tectonic phase (D2) was marked by vertical shear in two combined corridors: sinistral NNW-SSE and dextral NNE-SSW. The final stage of compression (D3) took place towards the end of the Eburnean orogeny. It would be held in two episodes. In the first episode, WNW-ESE stresses created conjugate shears: sinistral NNW-SSE and dextral NE-SW. In the second episode, stresses moved toward the NE-SW direction and made the resulting brittle structures arranged in NS dextral corridors. The Mako Group is thus affected by a polyphase tectonic. Black and white quartzites considered for several decades to be sedimentary rocks, in fact, come from the ultramylonitization and hydrothermalization of metagabbros, metabasalts, and metatuffs between D2 and D3 phase. An important circulation of fluid during this stage induced an intense epidotisation and silicification of these rocks.

\section{References}

[1] Bessoles, B. (1977) Géologie de l’Afrique-Le craton Ouest Africain. Mémoire B.R.G.M., France, 88, 403 p.

[2] Black, R. (1980) Precambrian of West Africa. Episodes, 4, 3-8.

[3] Bassot, J.P. (1966) Etude géologique du Sénégal oriental et de ses confins Guinéo-maliens. Mémoire B.R.G.M., France, 40, $332 \mathrm{p}$.

[4] Ndiaye, P.M., Dia, A., Vialette, Y., Diallo, D.P., Ngom, P.M., Sylla, M., Wade, S. and Dioh, E. (1997) Données pétrographiques, géochimiques et géochronologiques nouvelles sur les granitoïdes du Paléoprotérozoïque du Supergroupe du Dialé-Daléma (Sénégal oriental): Implications pétrogénétiques et géodynamiques. Journal of African Earth Sciences, 25, 193-208. http://dx.doi.org/10.1016/S0899-5362(97)00098-5

[5] Théveniaut, H., Ndiaye, P.M., Buscail, F., Couëffé, R., Delor, C., Fullgraf, T. and Goujou, J.C. (2010) Notice explicative de la carte géologique à 1/500 000 du Sénégal oriental. Ministère des Mines, de l'Industrie, de l'Agro-Industrie et des PME, Direction des Mines et de la Géologie, Dakar, 119 p.

[6] Dia, A. (1988) Caractères et significations des complexes magmatiques et métamorphiques du secteur de SandikoundaLamina (Nord de la Boutonnière de Kédougou). Un modèle géodynamique du Birimien de l'Afrique de l'Ouest. Thèse d’Etat, Université Cheikh Anta DIOP de Dakar, Sénégal, 350 p.

[7] Diallo, D.P. (1994) Caractérisation d'une portion de croûte d’âge protérozoïque inférieur du craton ouest africain: Cas de l'encaissant des granitoïdes dans le Supergroupe de Mako (boutonnière de Kédougou implications géodynamiques). Thèse de Doctorat d'Etat, Université Cheikh Anta Diop de Dakar, Sénégal, 466 p.

[8] Ngom, P.M. (1995) Caractérisation de la croûte birimienne dans les parties centrale et méridionale du Supergroupe de Mako. Implications géochimiques et pétrogénétiques. Thèse Doctorat d’Etat, Université Cheikh Anta Diop de Dakar, Sénégal, 243 p.

[9] Dioh, E. (1995) Caractérisation, signification et origine des formations birimiennes encaissantes du granit de Dioubalou (Partie septentrionale de la boutonnière de Kédougou-Kéniéba, Sénégal oriental). Thèse Doctorat d’Etat, Université Cheikh Anta DIOP de Dakar, Sénégal, 446 p.

[10] Bassot, J.P. and Vachette, C. (1984) Données géochronologiques et géochimiques nouvelles sur les granitoïdes de l’Est du Sénégal-Implication sur l'histoire géologique du Birimien dans cette région. In: Michot, J., Ed., Géologie Africaine, Tervuren, 191-209.

[11] Delor, C., Couëffé, R., Goujou, J.-C., Diallo, D.P., Théveniaut, H., Fullgraf, T., Ndiaye, P.M., Dioh, E., Blein, O., Barry, T.M.M., Cocherie, A., Le Métour, J., Martelet, G., Sergeev, S. and Wemmer, K. (2010) Notice explicative de la carte géologique à 1/200 000 du Sénégal, feuille Saraya-Kédougou Est. Ministère des Mines, de l’Industrie, de l’AgroIndustrie et des PME, Direction des Mines et de la Géologie, Dakar, 192 p.

[12] Junner, N.R. (1935) The Tarkwa Goldfield. Geological Survey Memoirs, 6, 75 p.

[13] Ledru, P., Pons, J., Milési, J.P., Feybesse, J.L. and Johan, V. (1991) Transcurrent Tectonics and Polycyclic Evolution in the Lower Proterozoïc of Sénégal—Mali (Afrique de l’Oest). Precambrien Research, 50, 139-165. http://dx.doi.org/10.1016/0301-9268(91)90028-9

[14] Hirdes, W. and Davis, D.W. (2002) U-Pb Geochronology of Paleoproterozoïc Rocks in the Southern Part of the Kédougou-Kéniéba-Inlier Sénégal, West Africa: Evidence for Diachronous Accrotionary Development of the Eburnean Province. Precambrian Research, 118, 83-99. http://dx.doi.org/10.1016/S0301-9268(02)00080-3

[15] Guèye, M., Siegesmund, S., Wemmer, K., Pawlig, S., Drobe, M. and Nolte, N. (2008) New Evidences for an Early Birimian Evolution in the West African Craton: An Example from the Kédougou-Kénieba Inlier, SE-Sénégal. South African Journal of Geology, 110, 179-190.

[16] Vidal, M., Gumiaux, C., Cagnard, F., Pouclet, A., Ouattara, G. and Pichon, M. (2009) Evolution of a Paleoproterozoïc 
(Weak Type) Orogeny in the West African Craton (Ivory Coast). Tectonophysics, 447, 145-159. http://dx.doi.org/10.1016/j.tecto.2009.02.010

[17] Sauwyer, E.W., Barnes, S.J. and Buck, M.J. (1983) Pillow Shelves: Determination of Beddind Direction and Structural Facing Direction for Shelves in Deformed Pillow Lavas. Canadian Journal of Earth Sciences, 20, 1483-1487. http://dx.doi.org/10.1139/e83-134

[18] More, J.G. and Charlton, D.W. (1984) Ultrathin Lavas Layers Exposed near San Luis Obispo Bay, California. Geology, 12, 542-545. http://dx.doi.org/10.1130/0091-7613(1984)12<542:ULLENS>2.0.CO;2

[19] Cissokho, S. (2012) Etude géologique du secteur de Mako (partie méridionale du Supergroupe de Mako, Boutonnière de Kédougou-Kéniéba, Sénégal oriental): Implication sur la diversité magmatique. Thèse de Doctorat Troisième Cycle, Université Cheikh Anta Diop de Dakar, Sénégal, 177 p.

[20] Diène, M., Guèye, M., Diallo, D.P. and Dia, A. (2012) Structural Evolution of a Precambrian Segment: Example of the Paleoproterozoïc Formations of the Mako Belt (Eastern Senegal, West Africa). International Journal of Geosciences, 3 , 153-165. http://dx.doi.org/10.4236/ijg.2012.31017

[21] Wilson, A.H. and Versfeld, A. (1994) The Early Archaen Nondweni Greenstone Belt, Southern Kaapvaal Craton, South Africa, Part I. Stratigraphy, Sedimentology, Mineralization and Depositional Environment. Precambrian Research, 67, 243-276. http://dx.doi.org/10.1016/0301-9268(94)90012-4

[22] Eugster, H.P. and Jones, B.F. (1968) Gels Composed of Sodium Aluminium Silicate, Lake Magadi, Kenya. Science, 1612, 160-163. http://dx.doi.org/10.1126/science.161.3837.160

[23] Naqvi, S.A., Govil, P.K. and Rogers, J.J.W. (1981) Chemical Sedimentation in Archaean-Early Proterozoïc Greenstone Belts of the Dharwar Craton, India. In: Glover, J.E. and Groves, D.I., Eds., Archean Geology: Second International Symposium, Perth, No. 7, Geological Society of Australia, 245-254. 